\title{
Sri Lanka: \\ Reports of Recent Violations of Human Rights and Amnesty International's Opposition to Refoulement of the Tamil Community to Sri Lanka
}

\author{
Amnesty International
}

During most of 1984, Amnesty International has requested governments not to send back to Sri Lanka, members of the Tamil minority in Sri Lanka seeking political asylum, or not wishing to return to their own country. Amnesty International continues to oppose the refoulement of Tamils because it believes that, if returned against their will, all members of the Tamil minority have reasonable grounds to fear:

1. that they may fall victim to arbitrary killings by members of the security forces; especially in view of reports of continuing and increasingly widespread shootings of unarmed members of the Tamil civilian population by members of the security forces apparently in reprisal for attacks on members of these forces by Tamil extremists groups:

2. that they may be subjected to arbitrary arrest and detention - particularly if they are men between 15-30 years old - and possibly be held incommunicado, with their relatives remaining unaware of their whereabouts for weeks and sometimes months after arrest:

3. that after arrest they may be subjected to ill-treatment and torture if the security forces believe that they have any knowledge of the activities of Tamil extremist groups.
Amnesty International has adopted this position because, although not all members of the Tamil community would necessarily be subjected to any of these human rights violations, there is a substantial possibility that they might be at risk. For general background see Report of an Amnesty International Mission to Sri Lanka 31 January - 9 February 1982 and the Amnesty International Report, Sri Lanka: Current Human Rights Concerns and Evidence of Extrajudicial Killings by the Security Forces July 1983-April 1984, published in June 1984 (the latter containing a summary of Amnesty International's human rights concerns up until December 1983).

Since the publication of the latter document in July 1984, Amnesty International has continued to receive reports of arbitrary arrest and detention, torture and most frequently of extrajudicial killings; reports which have increased at a time that Tamil extremists have, since mid-November 1984, stepped up their violent attacks in the north in their attempts to establish a separate state for the Tamil minority. Dozens of security forces personnel have been killed. For example, on 19 November 1984, members of Tamil extremists groups have claimed responsibility for the killing of the army commander in the northern region; on 20 November 1984 at least
27 police were killed in an attack at the Chavakachcheri police station by members of Tamil extremist groups, and on 30 November an estimated 65 men, women and children, all Sinhalese civilians, were killed by members of Tamil extremist groups at two farm settlements, Kent and Dollar Farms in the Mullaitivu district, used for the rehabilitation of convicted prisoners.

Amnesty has received extensive evidence indicating that despite denials by the government these and other attacks made by members of Tamil extremist groups have regularly been followed by reprisal killings of innocent Tamil civilians, including old men, women and children, carried out by personnel of the security forces. Particularly serious and widespread allegations of such extrajudicial killings by the security forces have been made from 1 December onwards. The allegations were accompanied by reports of large scale arrests of 'suspects' most of them members of the male Tamil population aged between 15 and 30 . Amnesty International had earlier received allegations that during detention without trail under the Prevention of Terrorism Act, illtreatment and torture continue to occur, such allegations having been made up until the time of writing. 